Section Editor

Mitchell S.V. Elkind, MD, MS

\section{Teaching NeuroImages: Isolated cervical spinal cord cysticercosis}

J.R. Lambertucci, PhD, MD

T.C. Vale, MD

A.C.G. Pereira, MD

S.R. Sousa-Pereira, MD

J.C.S. Dias, MD

M.S. Pedrosa, MD

M.M.R. Oliveira, $\mathrm{PhD}, \mathrm{MD}$

Address correspondence and reprint requests to Dr. José Roberto Lambertucci,

Department de Clínica Médica/ Faculdade de Medicina,

Universidade Federal de Minas Gerais, Avenida Alfredo Balena 190, CEP 30130-100 Belo

Horizonte, Minas Gerais, Brazil lamber@uai.com.br

Figure $1 \quad$ Sagittal T2-weighted spinal cord MRI
showing a cystic lesion with central
solid components ranging from C3 to
C5 vertebral bodies and medullary
edema extending toward the
cervical cord

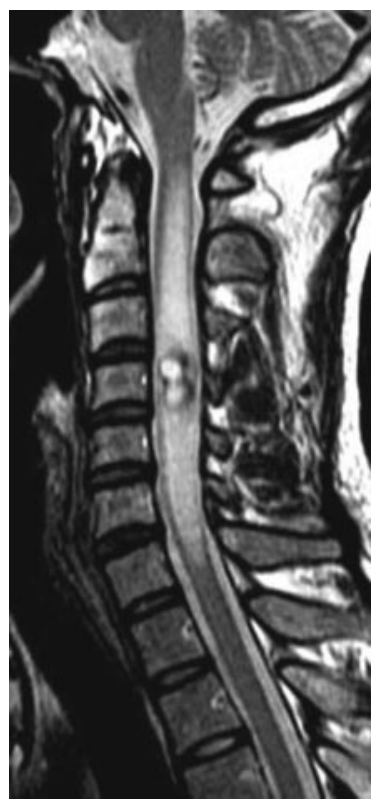

A 23-year-old Brazilian man, a farmer in a rural area of Minas Gerais State, complained of an 8-month history of neck pain and upper-limb weakness. Flaccid tetraparesis, global hyperreflexia, and pyramidal signs were present. Cranial CT and brain MRI were normal. Spinal cord MRI showed an intramedullary tumoral lesion, extending from C3 to C5 vertebral bodies, with a cystic appearance (figure 1). With a presumptive diagnosis of spinal cord tumor, the lesion was completely removed. Microscopy revealed the diagnosis of neurocysticercosis (figure 2). The patient was started on corticosteroids and albendazole with good functional recovery after 4 months. MRI showed only residual alterations caused by the surgical procedure.

CSF eosinophilia or a positive ELISA test to cysticerci are useful tools in the diagnosis of neurocysticercosis and

\begin{tabular}{|ll|}
\hline Figure 2 & Photomicrograph of the histopathologic \\
& specimen showing a cysticercus larva \\
& with its oval-shaped vesicle enclosed \\
in a cyst wall with outer cuticular, & \\
intermediate, and inner reticular & layers (hematoxylin-eosin, original \\
& magnification $\times 200)$
\end{tabular}



unfortunately were not performed in our patient. Isolated cervical intramedullary spinal neurocysticercosis is extremely rare and not considered by most physicians. ${ }^{1-3}$

\section{AUTHOR CONTRIBUTIONS}

Study concept and design: Dr. Lambertucci. Acquisition of data: Drs. Vale, Pereira, Sousa-Pereira, Dias, Pedrosa, Oliveira, and Lambertucci. Analysis and interpretation of data: Drs. Vale, Pereira, Sousa-Pereira, Dias, Pedrosa, and Oliveira. Drafting of the manuscript: Drs. Vale, Pereira, Sousa-Pereira, Dias, Pedrosa, Oliveira, and Lambertucci. Critical revision of the manuscript for important intellectual content: Drs. Oliveira and Lambertucci. Administrative, technical, and material support: Drs. Vale and Lambertucci.

\section{REFERENCES}

1. Ahmad FU, Sharma BS. Treatment of intramedullary spinal cysticercosis: report of 2 cases and review of literature. Surg Neurol 2007;67:74-77.

2. Chhiber SS, Singh B, Bansal P, Pandita KK, Razdan S, Singh J. Intramedullary spinal cysticercosis cured with medical therapy: case report and review of literature. Surg Neurol 2009;72:765-768.

3. Costa Júnior LB, Lemos SP, Lambertucci JR. Magnetic resonance imaging of racemous cysticercosis of the cauda equina. Rev Soc Bras Med Trop 2003;36:765-766.

From the Infectious Diseases Division (J.R.L., A.C.G.P.), Neurology Division, University Hospital (T.C.V., S.R.S.-P.), Neurosurgery Division (J.C.S.D., M.M.R.O.), and Pathology Division (M.S.P.), Faculty of Medicine, Federal University of Minas Gerais (UFMG), Belo Horizonte, Minas Gerais, Brazil. Disclosure: The authors report no disclosures. 


\section{Neurology}

Teaching NeuroImages: Isolated cervical spinal cord cysticercosis

J.R. Lambertucci, T.C. Vale, A.C.G. Pereira, et al.

Neurology 2011;77; e138

DOI 10.1212/WNL.0b013e31823b4753

\section{This information is current as of December 5, 2011}

\section{Updated Information \&} Services

References

Subspecialty Collections

Permissions \& Licensing

Reprints including high resolution figures, can be found at: http://n.neurology.org/content/77/23/e138.full

This article cites 3 articles, 0 of which you can access for free at: http://n.neurology.org/content/77/23/e138.full\#ref-list-1

This article, along with others on similar topics, appears in the following collection(s):

Clinical neurology history

http://n.neurology.org/cgi/collection/clinical_neurology_history

MRI

http://n.neurology.org/cgi/collection/mri

Parasitic infections

http://n.neurology.org/cgi/collection/parasitic_infections

Spinal cord infection

http://n.neurology.org/cgi/collection/spinal_cord_infection

Spinal cord tumor

http://n.neurology.org/cgi/collection/spinal_cord_tumor

Information about reproducing this article in parts (figures,tables) or in its entirety can be found online at:

http://www.neurology.org/about/about_the_journal\#permissions

Information about ordering reprints can be found online:

http://n.neurology.org/subscribers/advertise

Neurology ${ }^{\circledR}$ is the official journal of the American Academy of Neurology. Published continuously since 1951, it is now a weekly with 48 issues per year. Copyright Copyright (? 2011 by AAN Enterprises, Inc.. All rights reserved. Print ISSN: 0028-3878. Online ISSN: 1526-632X.

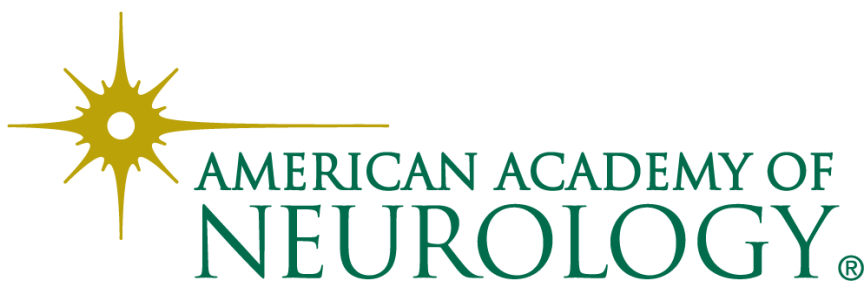

